\title{
Analysis on the relationship between teaching style and teaching performance of College Teachers
}

\author{
Liman Zhao ${ }^{1, \text { a }}$, Xiaoyun Chen ${ }^{1, b}$ \\ ${ }^{1}$ Jiangxi Science \& Technology Normal University, Nanchang, Jiangxi, 330013, China \\ alimzhao@126.com, ${ }^{b} 40905438 @ q q . c o m$
}

Keywords: University teaching; teaching style; teaching performance; relationship analysis

\begin{abstract}
China is currently in the stage of social reform, especially in the education is facing unprecedented challenges, the 21st century is a fierce competition in the market period, and market competition is mainly realized through competition for talent, but talent in our country at present, both in terms of quality also is the number, and Europe and the United States and other developed countries there is still a big gap compared to, can not meet the requirements of modernization construction of our country. The difficulties faced by the reform of the education system, the need to increase the quality of the teaching staff to complete. So training a variety of teaching styles, enhance students' learning interest, for the national training of creative talents, is an important part of the reform of the current education system. And teaching performance is the effective measures of teaching management, and it is also an important means to improve the quality of teaching, through the teaching performance can contribute to the quality of teaching information feedback, so as to continuously improve the diversification of teaching style to promote the professional development in Colleges and universities teaching in China, so the University to teach the teacher teaching style and teaching performance relationship analysis and new is particularly important.
\end{abstract}

\section{Introduction}

Through the analysis on the performance of teaching style and teaching, the teacher's teaching style to the direction of diversification, can according to different courses to choose different teaching style, can greatly improve the quality and level of teaching in Colleges and universities. In the actual teaching process, through continuous improvement of teaching style, improve the level of teaching in Colleges and universities, in order to promote the development of vocational college teachers. In this paper, the relationship of teaching style and performance analysis in ascension compete with teachers' teaching quality at the same time, for teachers to recognize the lack and perfected, thus forming diversified teaching style. It has great significance to the training of modern talents.

\section{Frequency analysis of the type of teaching style}

The five colleges in G University, University $\mathrm{P}, \mathrm{t}$ in the colleges and universities teaching style analysis, let the students of five kinds of teaching style humor active, caring, sharing, rigorous logic, the innovation and exploration type, simple and practical to his teacher for order, select the type of teaching style, that is, most of the students like teaching style and the five kinds of teaching style frequency analysis, and organized into a table 1

\begin{tabular}{ccccccc}
\hline 1 & 91 & 133 & 112 & 88 & 30 & 454 \\
2 & 52 & 54 & 78 & 124 & 146 & 454 \\
3 & 63 & 60 & 121 & 127 & 83 & 454 \\
4 & 133 & 125 & 83 & 68 & 45 & 454 \\
5 & 44 & 140 & 97 & 67 & 106 & 454 \\
\hline
\end{tabular}

Table 1 Table of frequency distribution of various teaching styles 
From table 1, you can clearly see, love to share teaching style occupy than not high of 133, followed by rigorous logic teaching style occupy 112 is the actual teaching process can put the two teaching style combined, collectively referred to as logic caring; analogy row name second teaching style are collectively referred to as the practical innovation; ranked third in the teaching style, collectively referred to as rigorous a model; ranked the fourth teaching style is love sharing, ranked in the top five is teaching style is humorous love type.

\section{The correlation analysis of teaching style and teaching performance}

Through the investigation and analysis of the types of teaching style through the frequency analysis of the high and low so, logical care, innovation and practicality, rigorous innovation, love sharing, humor care type. But in the actual teaching process, teachers' teaching style is diversity, there are great difference. In this paper, through the investigation and analysis summed up between different teaching styles and teaching performance have significant positive influence, summary graphs as shown in Table 2:

Table 2 Correlation Analysis of style and performance

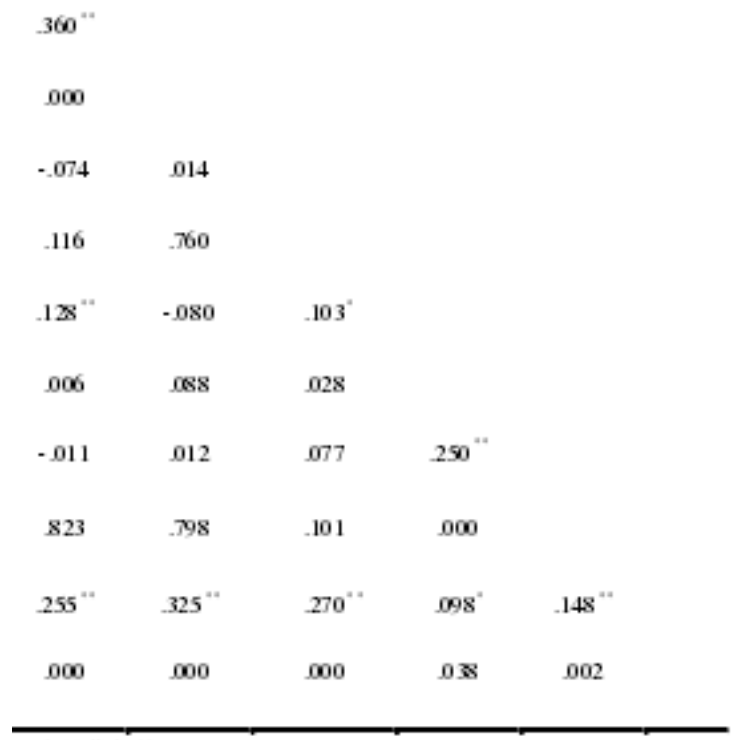

** Significant correlation at 0.01 level (bilateral)

* Significant correlation at 0.05 level (bilateral)

From table 2, we can clearly see, the teaching style of teaching performance at the 0.01 level bilateral has significant relationship and the logic relationship between teaching style and the teaching evaluation of the relatively high 0.359 . thus teaching style and performance in the presence of direct contact.

\section{Research on the relationship between teaching style and teaching performance}

In this paper improves the teaching style and the actual process of teaching style compared to the existence of many single by college students on Teachers' teaching style ranking research teaching style and teaching performance and components of the close degree, from table 2 can see clearly. Colleges and universities teaching style and performance level relationship between 0.01 level have clear relationships, and whether it is a kind of teaching style and teaching performance is greater than 0 , if let any three teaching style combination can positively predict the relationship between teaching style and performance, so in the teaching process of colleges and universities, every teacher to doping using at least three kinds of teaching style in order to guarantee the quality of teaching. 


\section{College attention and encouragement is the premise for teachers to form and improve the type of teaching style}

Implementation of the education reform in our country is in order to improve the quality of teaching, as a national training high-quality talents to meet the needs of the construction of the information society, through the above analysis it is clear to see that colleges and universities teaching style and performance have a significant relationship, so the major colleges and Universities to a high degree of training teachers' teaching style, through finding out the relevant literature summed up some measures to improve the teaching style and performance, hope that the development of education in our country has certain help.

5.1 colleges and universities need to provide information exchange and development platform School to form a unique style of teaching, that is to say that every teacher should have different teaching styles, for example in mechanical courses in the university education process, can have a variety of styles of teaching methods, the original machinery is a very boring subject, through the teacher students moving image transfer so that every student can understand the structure and principles of mechanical. At the same time to learn to take the initiative to build an information exchange platform, so that each teacher to communicate with each other, not only improve their teaching style. But each teacher's character, teaching subjects, age and so on are not the same, so in Colleges and universities should hold regular lecture, with each class, teaching style seminars and so on a series of platform for the teaching style of the teacher training. If conditions permit, select the excellent teachers to domestic famous universities to learn their teaching style, combined with their own actual situation, formulates suits the unique style of his own character and education discipline. The style in the process of training teachers' teaching style, the school also can hire rich teaching experience of the old professor for a series of lectures on teaching style, to listen to the teacher in class, and puts forward guidance, in order to improve the educational level and teaching quality of teachers, as a national training high-quality talent [3].

5.2 colleges and universities need to continuously improve the educational performance mechanism In our country a lot of colleges and universities management is more emphasis on the rules and regulations, and the development of the school, and despise the development of teachers' teaching style and personality. It will need to develop a series of educational performance competitive mechanism to change the management model of colleges and universities so that, in the process of classroom teaching, schools should attach importance to the teaching style and teaching personality, establish education style exchange platform, let the teachers learn from each other, mutual exchanges. On this basis, also continue to improve the mechanism of educational performance, the style of teaching and the quality of teaching, and teachers' teaching performance close contact, attach importance to the development of teaching performance mechanism, for good quality of teaching and the teachers were certain to encourage and play, for the existence of drain holes in the teaching way, timely and correct treatment. In order to mobilize the enthusiasm of teachers, in this process, we must put the teaching style as the index of teaching performance evaluation, can effectively improve the creativity of teachers teaching and improve the shortage of teachers teaching. In the actual teaching work, the formation of a unique teaching style, so as to ensure that colleges and universities in improving teaching performance at the same time to enhance the level of running a school.

5.3 in time to reflect on the improvement, the formation of a unique and effective style of teaching An excellent university teachers, just a taste of the previous economic education of college students, can not improve their teaching style even more excellent teaching performance. A psychologist has put forward a formula for growth: growth = experience + reflection. Only in the education of teachers in their work for a serious reflection, to find their own teaching problems, to find ways to improve their teaching level. Also each teacher has their own unique characteristics of teaching style type, according to the teacher's own personality changes and educational subjects, in the actual teaching work constantly improve their own teaching style, that is, teacher education work to continue to reflect on their own education short board, education in order to break through the bottleneck, improve teaching quality, for the country cultivate talents 


\section{Summary}

To sum up, this paper through the frequency analysis method and empirical analysis method, according to the analysis, and found that there is a positive predictor of the relationship between the teaching style and performance of the relationship between university teachers' teaching style, and teaching performance. Although this article has certain innovation in the analysis method, but also has many problems, through the analysis of the future research to improve and supplement. This paper to to teachers and students of five universities as the object of study, and questionnaire survey, so in the sample selection has certain representativeness, but our country is vast in territory, each region have their unique culture and values, so in the teaching process of colleges and universities, the style of education such as the existence of great difference, the sample may be used with the raise of five universities, which cannot be explained by the style of education and teaching performance, just want to for China's colleges and universities in the research on teaching style and performance have certain help.

This paper is the research and practice of teaching quality evaluation system of College Teachers' education and teaching reform in Colleges and Universities: a case study of Jiangxi Science \& Technology Normal University as an example. The Topic number of the research: JXJG-15-10-20

\section{References}

[1] Cheng Hongyu. Study on the relationship between the differences of Chinese and American College Teachers' teaching styles and the classroom learning behavior of college students [J]. applied psychology, 2014,03:234-242+262.

[2] Zhou Jingkun, Wu Jinli. The application of the professional team approach to the performance evaluation of mature teachers [J]. Heilongjiang higher education research, 2015,04:14-18.

[3] Liu Beini. Evolutionary game analysis of the teaching performance evaluation of college teachers [J]. education and teaching research, 2015,12:28-33.

[4] Yin Rui, Ni Miaoshan, Sun Ningyu, Yang Yang. Performance analysis of the construction of information teaching ability of University Teachers -- Based on the survey data of 10 universities in [J]. province G China education information, 2016,04:71-75. 